\title{
PENGARUH KERELASIAN PEMASARAN DAN KUALITAS PRODUK TERHADAP KEPUASAN PELANGGAN PADA PT ASRI PANCAWARNA
}

\author{
Yuli Evitha \\ Institut Ilmu Sosial dan Manajemen STIAMI \\ email:yuli.evitha@gmail.com
}

\begin{abstract}
Abstrak. Fenomena masih adanya keluhan sebagai ekspresi ketidakpuasan pelanggan PT. Asri Pancawarna/ APW, menjadi dasar atau tujuan penelitian ini. Penelitian ini bertujuan untuk mengetahui pengaruh kerelasian pemasaran $\left(\mathrm{X}_{1}\right)$ dan kualitas produk $\left(\mathrm{X}_{2}\right)$, baik secara partial maupun simultan terhadap kepuasan pelanggan (Y).

Guna mencapai tujuan penelitian tersebut, penelitian ini menggunakan instrumen kuesioner yang dikembangkan berdasarkan dasar teoretik dan disusun dalam Skala Likert. Sampel dalam penelitian ini diambil dengan simple random sampling sejumlah 67. Sedangkan teknik analisis data yang digunakan adalah regresi linier berganda.

Hasil penelitian menunjukkan bahwa Kerelasian Pemasaran berpengaruh terhadap Kepuasan Pelanggan, demikian juga Kualitas Produk berpengaruh terhadap Kepuasan Pelanggan. Variabel Kerelasian Pemasaran dan Kualitas Produk dapat menjelaskan atau berkontribusi sebesar 98,2 \% terhadap Kepuasan Pelanggan.
\end{abstract}

Kata Kunci: Kerelasian Pemasaran, Kualitas Produk, Kepuasan Pelanggan, Regresi Linier Berganda

\begin{abstract}
The phenomenon that occurs today is the dissatisfaction of customers of PT. Asri Pancawarna / APW, became the basis or purpose of this study. This study aims to determine the content of relation (X1) and product quality (X2), either partially or simultaneously to customer satisfaction $(Y)$.

In order to achieve the objectives of the study, this study used questionnaire instruments developed and arranged in Likert Scale. The sample in this study was taken with simple random sampling amount of 67. While the data analysis technique is multiple linear regression.

The results showed that Marketing Relationship Against Customer Satisfaction, as well as Product Quality of Customer Density Properties. Marketing Relation Variables and Product Quality can cause $98.2 \%$ of Customer Satisfaction.
\end{abstract}

Keywords: Marketing Relation, Product Quality, Customer Satisfaction, Multiple Linear Regression 
Yuli Evitha, Pengaruh Kerelasian Pemasaran Dan Kualitas Produk Terhadap Kepuasan Pelanggan ....

\section{PENDAHULUAN}

Pemasaran menjadi semakin penting dalam dinamika dunia usaha dewasa ini. Perusahaan harus menentukan strategi pemasaran yang tepat agar dapat survive dalam kancah persaingan global. Strategi tersebut tidak saja berorientasi kedalam perusahaan, terkait kekuatan perusahaan, tetapi juga berorientasi keluar, yakni dengan memelihara dan memperhatikan kebutuhan konsumen.

Pemeliharaan hubungan dan pemenuhan kebutuhan akan berpengaruh terhadap kepuasan konsumen. Dengan terciptanya kepuasan, maka perusahaan akan memperoleh manfaat, antara lain adanya hubungan harmonis pelanggan-perusahaan, terbukanya peluang pembelian ulang, serta potensi rekomendasi oleh konsumen kepada calon konsumen lain.

Dalam konteks demikian, perusahaan telah mampu membangun relationship marketing sebagai suatu filosofi atau budaya perusahaan dengan meletakkan perhatian terhadap pelanggan penting secara terfokus dan terus menerus.

Saat ini perusahaan harus mulai fokus pada penyampaian nilai (value) dan meningkatkan loyalitas pelanggan. Loyalitas berarti konsumen kembali dan kembali lagi untuk melakukan transaksi bisnis (pembelian), walaupun mungkin produk yang dimiliki perusahaan bukan produk terbaik di pasaran atau memiliki harga terendah. Perilaku konsumen yang cukup "tidak rasional" ini dapat dijelaskan dengan suatu pandangan bahwa "hubungan baik" (good relationship) yang terjalin dengan konsumen merupakan kunci keberhasilan sebuah perusahaan dalam mempertahankan pelanggan.

Dengan persaingan yang ketat konsumen memiliki peluang yang luas untuk mendapatkan produk yang sesuai dengan keinginan dan kebutuhannya, sehingga untuk memenuhi hal tersebut sebuah perusahaan harus mampu menyediakan produk yang mutunya lebih baik, harganya lebih murah, informasi yang lebih cepat serta pelayanan yang lebih baik dibandingkan dengan pesaingnya. Oleh sebab itu, berbagai upaya dilakukan agar hubungan pelanggan dengan perusahaan berjalan dengan baik, dengan harapan segala produk yang ditawarkan dapat memuaskan pelanggan dan hubungan atau relatios dapat terus berjalan dengan baik.

Kepuasan pelanggan merupakan hasil akhir yang diinginkan oleh setiap perusahaan. Kepuasan pelanggan ialah tingkat perasaan seseorang setelah membandingkan kinerja (atau hasil) yang dirasakan dibandingkan dengan harapannya (Kotler:1994). Pelanggan akan merasa puas apabila hasil yang didapatkan sama dengan harapan yang diinginkan. Begitu pula sebaliknya, pelanggan akan merasa tidak puas apabila hasil ia dapatkan dibawah ekspektasi yang diinginkan. Saat ini, perusahaan modern tidak lagi hanya mengharapkan suatu kepuasan pelanggan standar atau hanya puas. Namun, suatu perusahaan berharap pelanggan sangat puas atas pelayanan dan produk yang diberikan.

PT. APW memiliki banyak pelanggan. Hal ini dikarenakan PT. APW menerapkan suatu kerelasian pemasaran dengan pelanggannya. Namun demikian, kerelasian pemasaran ini tidak berjalan maksimal. PT. APW masih sering menerima keluhan terkait kinerja pemasar. Kritik pelanggan PT. APW tersebut merupakan suatu ketidakpuasan. Apabila kritik pelanggan PT. APW terus meningkat, maka PT. APW dapat ditinggalkan oleh pelanggan dimana pelanggan akan mencari perusahaan lain yang memberikan apa yang pelanggan inginkan.

\section{a. Permasalahan}

Permasalahan dalam penelitian ini dirumuskan sebagai berikut:

1. Seberapa besar pengaruh kerelasian pemasaran terhadap kepuasan pelanggan di PT. Asri Pancawarna?

2. Seberapa besar pengaruh kualitas produk terhadap kepuasan pelanggan di PT. Asri Pancawarna ?

3. Seberapa besar pengaruh kerelasian pemasaran dan kualitas produk secara simultan terhadap kepuasan pelanggan di PT. Asri Pancawarna? 


\section{b. Tujuan}

1. Mengetahui besarnya pengaruh kerelasian pemasaran terhadap kepuasan pelanggan di PT. Asri Pancawarna.

2. Mengetahui besarnya pengaruh kualitas produk terhadap kepuasan pelanggan di PT. Asri Pancawarna,

3. Mengetahui besarnya pengaruh kerelasian pemasaran dan kualitas produk secara simultan terhadap kepuasan pelanggan di PT. Asri Pancawarna.

\section{c. Signifikansi}

\section{Akademik}

Manfaat akademik penelitian ini ialah sebagai referensi teori dan konsep tentang kualitas produk dan kerelasian pemasaran terhadap kepuasan konsumen produk keramik granit.

\section{Kebijakan}

Manfaat kebijakan penelitian ini ialah sebagai bahan referensi manajemen PT. APW dalam membuat kebijakan terkait peningkatan kepuasan konsumen melalui kualitas produk dan kerelasian pemasaran.

\section{Praktis}

Manfaat praktis penelitian ini ialah untuk meningkatkan kepuasan konsumen melalui kualitas produk dan kerelasian pemasaran bagi PT. APW.

\section{d. Temuan dan Kontribusi}

Temuan yang diharapkan dari penelitian ini adalah gambaran pengaruh antara kerelasian pemasaran dan kualitas produk terhadap kepuasan pelanggan.

Kontribusi penelitian ini terhadap ilmu pengetahuan adalah sebagai berikut:
1. Memperkaya khazanah ilmu pemasaran;
2. Menguji teori-teori tentang pemasaran, kualitas produk, dan kepuasan pelanggan secara empiric.

\section{KAJIAN LITERATUR}

\section{Penelitian Terdahulu}

a. Keterkaitan Kualitas Produk dengan Kepuasan Pelanggan

Tabel 2-1

Resume Penelitian Terdahulu tentang Keterkaitan Kualitas Produk dengan Kepuasan Pelanggan

\begin{tabular}{|c|c|c|}
\hline $\begin{array}{l}\text { Nama Peneliti, } \\
\text { Tahun, Judul }\end{array}$ & Tujuan Penelitian & $\begin{array}{l}\text { Metode, Objek, Variabel, } \\
\text { Hasil }\end{array}$ \\
\hline $\begin{array}{l}\text { Saidani \& Arifin (2012) } \\
\text { Pengaruh Kualitas } \\
\text { Produk dan Kualitas } \\
\text { Layanan terhadap } \\
\text { Kepuasan Konsumen } \\
\text { dan Minat Beli pada } \\
\text { Ranch Market }\end{array}$ & $\begin{array}{l}\text { Untuk menguji pengaruh } \\
\text { kualitas pelayanan dan kualitas } \\
\text { produk terhadap minat beli } \\
\text { ulang melalui mediasi kepuasan } \\
\text { konsumen di Ranch Market } \\
\text { Untuk menguji pengaruh } \\
\text { kualitas produk dan kualitas } \\
\text { layanan terhadap kepuasan } \\
\text { konsumen di Ranch Market } \\
\text { Untuk menguji pengaruh } \\
\text { kualitas produk dan kualitas } \\
\text { layanan terhadap minat beli } \\
\text { ulang di Ranch Market } \\
\text { Untuk menguji pengaruh }\end{array}$ & $\begin{array}{l}\text { Metode : kuantitatif, eksplanatif } \\
\text { Objek: pelanggan Ranch Market } \\
\text { Pondok Indah } \\
\text { Variabel: } \\
\text {-Kualitas layanan } \\
\text {-Kualitas produk } \\
\text {-Kepuasan konsumen } \\
\text {-Minat pembelian ulang } \\
\text { Hasil: } \\
\text { Kualitas layanan dan kualitas } \\
\text { produk berpengaruh terhadap } \\
\text { minat beli ulang melalui mediasi } \\
\text { kepuasan konsumen di Ranch } \\
\text { Market }\end{array}$ \\
\hline
\end{tabular}


Yuli Evitha, Pengaruh Kerelasian Pemasaran Dan Kualitas Produk Terhadap Kepuasan Pelanggan ....

\begin{tabular}{|c|c|c|}
\hline $\begin{array}{l}\text { Nama Peneliti, } \\
\text { Tahun, Judul }\end{array}$ & Tujuan Penelitian & $\begin{array}{c}\text { Metode, Objek, Variabel, } \\
\text { Hasil }\end{array}$ \\
\hline & $\begin{array}{l}\text { kepuasan konsumen terhadap } \\
\text { minat beli ulang di Ranch } \\
\text { Market }\end{array}$ & $\begin{array}{l}\text { Kualitas produk dan kualitas } \\
\text { layanan berpengaruh terhadap } \\
\text { kepuasan konsumen di Ranch } \\
\text { Market } \\
\text { Kualitas produk dan kualitas } \\
\text { layanan berpengaruh terhadap } \\
\text { minat beli ulang di Ranch Market } \\
\text { Kepuasan konsumen berpengaruh } \\
\text { terhadap mina beli ulang di Ranch } \\
\text { Market }\end{array}$ \\
\hline $\begin{array}{l}\text { Lasander (2013) } \\
\text { Citra Merek, Kualitas } \\
\text { Produk dan Promosi } \\
\text { Pengaruhnya Terhadap } \\
\text { Kepuasan Konsumen } \\
\text { pada Makanan } \\
\text { Tradisonal }\end{array}$ & $\begin{array}{l}\text { Pengaruh citra merek, kualitas } \\
\text { produk dan promosi secara } \\
\text { bersama terhadap kepuasan } \\
\text { konsumen pada makanan } \\
\text { tradisonal di Tahuna Sangihe } \\
\text { Pengaruh citra merek terhadap } \\
\text { kepuasan konsumen pada } \\
\text { makanan tradisional di Tahuna } \\
\text { Sangihe } \\
\text { Pengaruh kualitas produk } \\
\text { terhadap kepuasan konsumen } \\
\text { pada makanan tradisonal di } \\
\text { Tahuna Sangihe } \\
\text { Pengaruh promosi terhadap } \\
\text { kepuasan konsumen pada } \\
\text { makanan tradisional di Tahuna } \\
\text { Sangihe }\end{array}$ & $\begin{array}{l}\text { Metode: Kuantitatif, ekspalantif } \\
\text { Objek: Konsumen makanan } \\
\text { tradisonal di Tahuna Sangihe } \\
\text { Variabel: } \\
\text {-Citra merek } \\
\text {-Kualitas produk } \\
\text {-Promosi } \\
\text {-Kepuasan konsumen } \\
\text { Hasil: } \\
\text {-Citra merek, kualitas produk dan } \\
\text { promosi secara simultan } \\
\text { berpengaruh terhadap kepuasan } \\
\text { konsumen } \\
\text {-Citra merek berpengaruh } \\
\text { signifikan terhadap kepuasan } \\
\text { konsumen } \\
\text {-Kualitas produk berpengaruh } \\
\text { signifikan terhadap kepuasan } \\
\text { konsumen } \\
\text {-Promosi berpengaruh signifikan } \\
\text { terhadap kepuasan konsumen }\end{array}$ \\
\hline
\end{tabular}

b. Keterkaitan Kerelasian Pemasaran dengan Kepuasan Pelanggan

Tabel 2-2

Resume Penelitian Terdahulu tentang Keterkaitan Kerelasian Pemasaran dengan Kepuasan Pelanggan.

\begin{tabular}{|l|l|l|}
\hline \multicolumn{1}{|c|}{$\begin{array}{c}\text { Nama Peneliti, } \\
\text { Tahun, Judul }\end{array}$} & \multicolumn{1}{|c|}{ Tujuan Penelitian } & \multicolumn{1}{c|}{$\begin{array}{c}\text { Metode, Objek, Variabel, } \\
\text { Hasil }\end{array}$} \\
\hline $\begin{array}{l}\text { Velnampy \& Sivesan } \\
(2012)\end{array}$ & $\begin{array}{l}\text { Untuk mengetahui pengaruh } \\
\text { kerelasian pemasaran terhadap } \\
\text { kepuasan pelanggan }\end{array}$ & $\begin{array}{l}\text { Metode: kuantitatif } \\
\text { Objek: konsumen mobile service } \\
\text { providing di Srilanka }\end{array}$ \\
\hline
\end{tabular}




\begin{tabular}{|c|c|c|}
\hline $\begin{array}{c}\text { Nama Peneliti, } \\
\text { Tahun, Judul }\end{array}$ & Tujuan Penelitian & $\begin{array}{c}\text { Metode, Objek, Variabel, } \\
\text { Hasil }\end{array}$ \\
\hline $\begin{array}{l}\text { Marketing and } \\
\text { Customer Satisfaction: } \\
\text { A Study on Mobile } \\
\text { Service Providing } \\
\text { Companies in Srilanka }\end{array}$ & & $\begin{array}{l}\text { Variabel: } \\
\text {-Customer Relationship } \\
\text { Marketing } \\
\text {-Customer Satisfaction } \\
\text { Hasil: } \\
\text { Kerelasian pemasaran } \\
\text { memberikan pengaruh yang } \\
\text { signifikan terhadap kepuasan } \\
\text { pelangganservice providing di } \\
\text { Srilanka }\end{array}$ \\
\hline $\begin{array}{l}\text { Al-Hersh et al (2014) } \\
\text { The Impact of } \\
\text { Customer Relationship } \\
\text { Marketing on Customer } \\
\text { Satisfaction of the Arab } \\
\text { Bank Services }\end{array}$ & $\begin{array}{l}\text { Untuk mengetahui pengaruh } \\
\text { yang diberikan oleh kerelasian } \\
\text { pemasaran terhadap kepuasan } \\
\text { pelanggan pada industri } \\
\text { perbankan di Saudi Arabia dan } \\
\text { Jordan }\end{array}$ & $\begin{array}{l}\text { Metode: kuantitatif } \\
\text { Objek: nasabah industri } \\
\text { perbankan di Rab Saudi dan } \\
\text { Jordan } \\
\text { Variabel: } \\
\text {-Kerelasian Pemasaran } \\
\text {-Kepuasan Pelanggan } \\
\text { Hasil: } \\
\text { Kerelasian pemasarn memberikan } \\
\text { pengaruh yang signifikan } \\
\text { terhadap kepuasan pelanggan } \\
\text { industri perbankan di Arab Saudi } \\
\text { dan Jordan }\end{array}$ \\
\hline
\end{tabular}

\section{Kerelasian Pemasaran}

\section{a. Pengertian Kerelasian Pemasaran}

Pemasaran merupakan suatu proses mempersepsikan, pemahami, menstimulasi dan memenuhi kebutuhan pasar sasaran yang dipilih secara khusus dengan menyalurkan sumber-sumber sebuah organisasi untuk memenuhi kebutuhan-kebutuhan tersebut. Dengan demikian, pemasaran merupakan proses penyelarasan sumber-sumber sebuah organisasi terhadap kebutuhan pasar. Pemasaran memberi perhatian pada hubungan timbal balik yang dinamis antara produkproduk dan jasa-jasa perusahaan, keinginan dan kebutuhan konsumen, dan kegiatankegiatan para pesaing. (Payne, 2005:27).

Menurut Kotler (2005) kegiatan pemasaran dalam suatu perusahaan dilakukan untuk mencapai tujuan perusahaan, yang berusaha meletakkan pemasaran sebagai pusat kegiatan dan memandu semua unit yang diproduksi ke arah pencapaian tujuan perusahaan. Untuk menuju tercapainya tujuan perusahaan ini diperlukan konsep pemasaran. Konsep pemasaran merupakan sebuah kunci untuk mencapai tujuan organisasiyang terdiri dari penentuan kebutuhan dan keinginan pasar sasaran serta memberikan kepuasan yang diharapkan secara lebih efektif dan efisien. Untuk mengetahui pemahaman kerelasian pemasaran dalam upaya untuk memuaskan pelanggan diperlukan adanya hubungan atau relasi dengan pelanggan (customer relations) di dalam memasarkan produk.

Menurut Edward L. Berney dalam Moore (2005:514) memberikan pengertian customer relations sebagai proses dari beberapa tahapan yang terdiri dari identifikasi dan pengembangan customer yang memberikan kontribusi yang besar terhadap perusahaan dengan cara memfokuskan strateginya yaitu dengan cara menjaga 
Yuli Evitha, Pengaruh Kerelasian Pemasaran Dan Kualitas Produk Terhadap Kepuasan Pelanggan ....

hubungan tersebut menjadi hubungan yang menguntungkan baik bagi pihak lembaga/perusahaan maupun pihak konsumen.

Customer relations melingkupi semua aspek yang berhubungan dengan calon konsumen dan konsumen saat ini. Konsumen adalah setiap orang, unit atau pihak dengan siapa kita bertransaksi, baik langsung maupun tidak langsung dalam penyediaan produk/jasa. Konsumen sering diposisikan sebagai orang luar dan produsen/perusahaan adalah orang dalam. Akibatnya konsumen dianggap sebagai pihak lain. Saat ini kita masih mendengungkan bahwa konsumen itu bagaikan raja.

Customer relations bertujuan untuk menyediakan umpan yang lebih efektif dan integrasi yang lebih baik. Fungsi-fungsi dalam Customer Relations sebuah sistem harus bisa menjalankan fungsi :

1. Mengidentifikasi faktor-faktor yang penting bagi pelanggan

2. Mengusung falsafah custamer-oriented.

3. Mengadopsi pengukuran berdasarkan sudut pandang pelanggan.

4. Membangun proses ujung ke ujung dalam melayani pelanggan

5. Menyediakan dukungan pelanggan yang sempurna.

6. Menangani keluhan/komplain pelanggan.

7. Mencatat dan mengikuti semua aspek dalam penjualan.

8. Membuat informasi holistik tentang infomasi layanan dan penjualan dari pelanggan.

Hubungan dengan pelanggan diperlukan managemen atau dikelola dengan baik oleh perusahaan. Manajemen hubungan kerelasian pelanggan atau biasa disebut Customer Relationship Management (CRM), merupakan proses pengelolaan informasi tentang pelanggan dari berbagai aspeknya.

\section{b. Teori Kerelasian Pemasaran}

Seth \& Sisodia (Seth \& Parvatiyar:1995:400) menyebutkan bahwa tujuan dari relationship marketing atau kerelasian pemasaran ialah untuk menambah produktivitas pemasaran melalui efisiensi dam efektivitas. Beberapa kegiatan kerelasian pemasaran dapat membantu meningkatkan efisiensi seperti retensi pelanggan (customer retention), respon pelanggan yang efisien (Efficient Consumer Response - ECR) dan pembagian sumber daya antar mitra pemasaran. Efektivitas pemasaran tercapai karena perusahaan melibatkan pelanggan dalam tahap awal pengembangan program pemasaram, memfasilitasi upaya pemasaran perusahaan di masa depan. Selain itu melalui pemasaran individual dan penerapan proses kustomisasi massal, pemasar dapat menentukan kebutuhan yang diinginkan pelanggan.

Relationship marketing tidak hanya menekankan pada hubungan perusahaan dengan konsumen saja, melainkan juga pada hubungan perusahaan dengan supplier, internal dan organisasi lainnya.

\section{Kualitas Produk}

a. Pengertian Kualitas Produk

Menurut Kotler \& Amstrong (2012:283) kualitas produk ialah kemampuan sebuah produk dalam memperagakan fungsinya, hal itu termasuk keseluruhan durabilitas, reliabilitas, ketepatan, kemudahan pengoperasian dan reparasi produk. Lain halnya dengan Hansen \& Mowen (2004:41) mendefinisikan kualitas produk sebagai tingkat keunggulan (excellence) atau ukuran relatif dari kebaikan (goodness). Dari kedua definisi tersebut dapat disimpulkan bahwa kualitas produk ialah kebaikan produk dalam menjalankan fungsinya.

Berdasarkan pengertian di atas, dapat disimpulkan bahwa kualitas produk sebagai ukuran relative.

Menurut Supriyono (1994:377:378), terdapat dua jenis kualitas yakni :

a. Quality of Design (Kualitas Rancangan)

b. Quality of Conformance (Kualitas Kesesuaian)

\section{Kepuasan Pelanggan}

\section{a. Pengertian Kepuasan Pelanggan}

Zeithaml \& Bitner (2008:110) mendefiniskan kepuasan pelanggan sebagai respon pelanggan terhadap evaluasi ketidaksesuaian yang dirasakan antara harapan dan kinerja aktual. Kepuasan 
pelanggan menurut Irawan (2008:37) kepuasan pelanggan ditentukan oleh persepsi atas performance produk atau jasa dalam memenuhi harapan pelanggan. Adapun menurut Kotler (1997:36), kepuasan pelanggan ialah perasaan senang atau kecewa seseorang yang berasal dari perbandingan antara kesannya terhadap kinerja (hasil) suatu produk dengan harapannya.

Dalam pengertian kepuasan pelanggan menurut beberapa ahli, maka dapat disimpulkan bahwa kepuasan pelanggan merupakan hasil kinerja suatu produk bila dibandingkan dengan harapan yang diinginkan. Kepuasan pelanggan merupakan hasil akhir yang diinginkan oleh semua produsen produk maupun jasa.

\section{KERANGKA PEMIKIRAN}

Kerelasian pemasaran merupakan cara untuk lebih mengenal konsumen dengan baik. Hubungan ini tidak hanya berupa hubungan dengan konsumen, melainkan juga dengan organisasi lainnya. Program kerelasian pemasaran ini terdiri dari continuity marketing, one to one marketing dan partnering program (Sheth et al:1999:21-23). Dalam beberapa penelitian terdahulu menunjukkan bahwa kerelasian pemasaran memberikan pengaruh yang signifikan terhadap kepuasan pelanggan.

Kualitas produk ialah kebaikan produk dalam menjalankan fungsinya. Kualitas produk merupakan salah satu faktor yang mempengaruhi kepuasan pelanggan. Adapun dimensi yang membentuk kualitas produk menurut Mullins et al (2005:422) ialah performance (kinerja),durability (daya tahan),features (fitur), reliability (keandalan), conformance to specification (kesesuaian dengan spesifikasi), aesthetics (estetika) dan perceived quality (citra \& reputasi produk). Peneliti menggunakan dimensi durability (daya tahan), reliability (keandalan), conformance to specification (kesesuaian dengan spesifikasi), danaesthetics (estetika). Adapun kepuasan pelanggan merupakan hasil akhir yang diinginkan oleh semua produsen produk maupun jasa. Konsumen akan membandingkan harapan yang bangun pada saat membeli produk dengan hasil produk yang diterima. Kepuasan pelanggan dibentuk oleh beberapa faktor yang pada penelitian ini ialah kerelasian pemasaran dan kualitas produk. Dimensi kepuasan pelanggan terdiri dari harapan umum, pengalaman yang diperoleh serta kepuasan keseluruhan (Qing \& Victor : 2008). Peneliti menggunakan dua dimensi yakni harapan umum dan kepuasan keseluruhan.

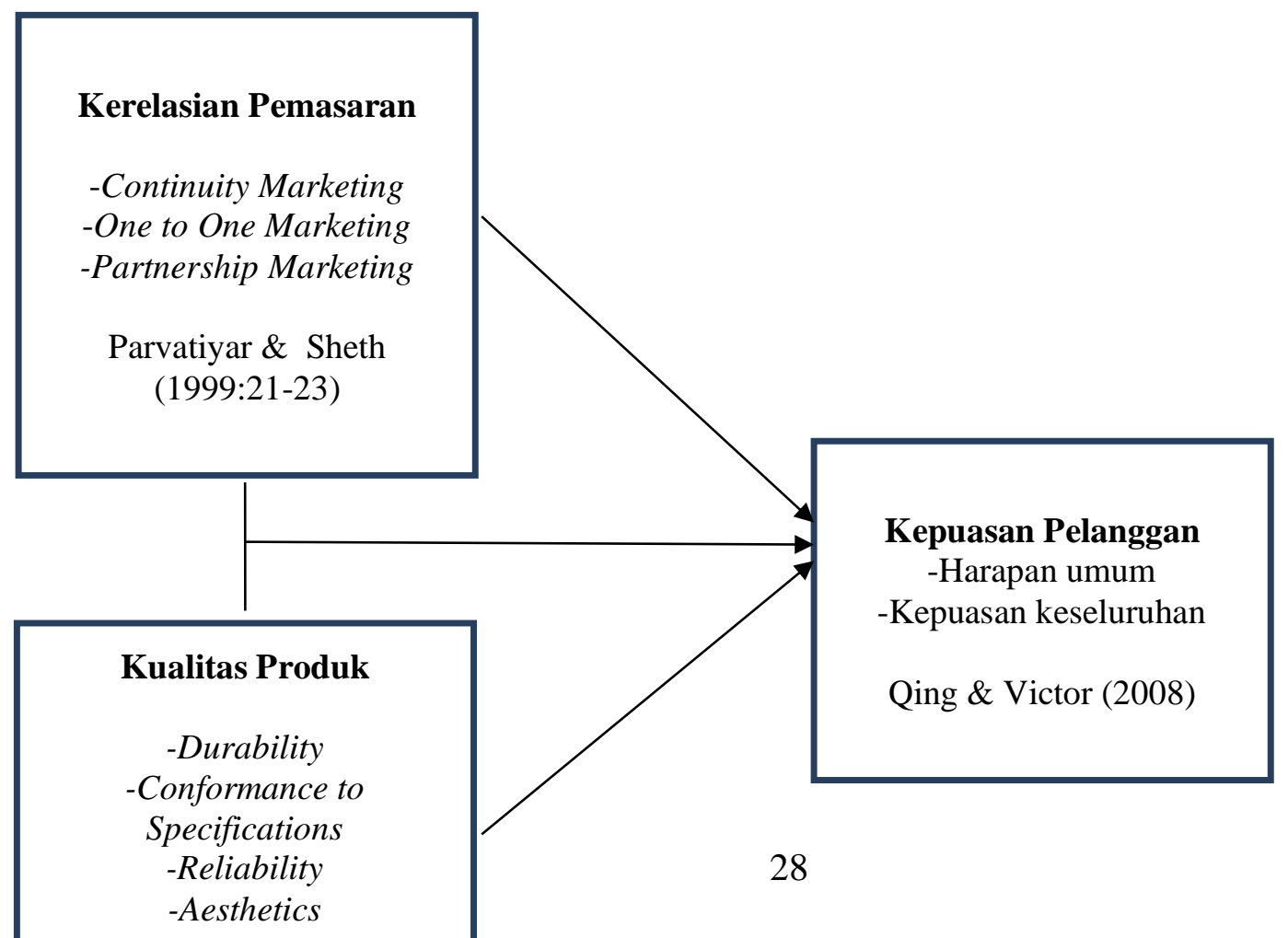


Gambar Kerangka Pemikiran

\section{Hipotesis}

Hipotesis merupakan pernyataan yang dapat diuji mengenai hubungan antara dua variabel atau lebih. Berdasarkan latar belakang, perumusan masalah, tujuan dan kegunaan, landasan teori dan kerangka pikir, maka dapat ditarik beberapa hipotesis, yakni:

1. Hipotesis 1: Pengaruh Kerelasian Pemasaran terhadap Kepuasan Pelanggan PT. Asri Pancawarna (PT APW)

Ho: tidak terdapat pengaruh yang signifikan yang diberikan kerelasian pemasaran terhadap kepuasan pelanggan PT. Asri Pancawarna (PT APW)

$\mathrm{H} 1$ : terdapat pengaruh yang signifikan yang diberikan kerelasian pemasaran terhadap kepuasan pelanggan PT. Asri Pancawarna (PT APW)

2. Hipotesis 2: Pengaruh Kualitas Produk terhadap Kepuasan Pelanggan PT. Asri Pancawarna (PT APW)

Ho: tidak terdapat pengaruh yang signifikan yang diberikan kualitas produk terhadap kepuasan pelanggan PT. Asri Pancawarna (PT APW)

H1: tidak terdapat pengaruh yang signifikan yang diberikan kualitas produk terhadap kepuasan pelanggan PT. Asri Pancawarna (PT. APW).
3. Hipotesis 3: Pengaruh Kerelasian Pemasaran dan Kualitas Produk terhadap Kepuasan Pelanggan PT. Asri Pancawarna (PT. APW).

Ho: tidak terdapat pengaruh yang signifikan yang diberikan kerelasian pemasaran dan kualitas produk terhadap kepuasan pelanggan PT. Asri Pancawarna (PT. APW).

H1: : tidak terdapat pengaruh yang signifikan yang diberikan kerelasian pemasaran dan kualitas produk terhadap kepuasan pelanggan PT. Asri Pancawarna (PT. APW).

\section{METODE PENELITIAN}

Pendekatan yang digunakan peneliti
adalah pendekatan positivism yakni pendekatan yang sangat dipengaruhi oleh kaedah-kaedah ilmu alam yang tujuannya adalah scientific explanation (Neuman : 2007 : 42). Metode yang digunakan adalah metode penelitian deskriptif ekspalanatif secara kuantitatif.

Dalam penelitian ini, peneliti menggunakan data primer. Adapun data primer diperoleh dengan cara penyebaran kuesioner dengan Skala Likert yakni :

\begin{tabular}{|l|c|}
\hline \multicolumn{1}{|c|}{ Jawaban } & Skor \\
\hline Sangat Setuju (SS) & 5 \\
\hline Setuju (S) & 4 \\
\hline Cukup Setuju (CS) & 3 \\
\hline TidakSetuju (TS) & 2 \\
\hline SangatTidakSetuju (STS) & 1 \\
\hline
\end{tabular}

Selain melalui teknik kuesioner, peneliti juga melakukan observasi. Obeservasi merupakan cara pengumpulan data melalui proses pencatatan perilaku subjek (orang), objek (benda) atau kejadian yang sistematik tanpa adanya pertanyaan ataupun komunikasi 
dengan individu-individu yang akan diteliti.

Data sekunder juga digunakan peneliti dalam penelitian ini. Data sekunder berupa jumlah pelanggan, variasi produk didapatkan dari PT. APW. Data sekunder ini sebagai data pendukung.

Populasi penelitian ini ialah seluruh pelanggan PT. APW. Pelanggan PT. APW berjumlah 200.
Ukuran unit sampling (dari setiap unit kerja), ditetapkan secara proporsional seperti ditunjukkan pada uraian tabel 3-4 berikut : Tabel Populasi dan Sampel Penelitian

\begin{tabular}{|c|c|c|c|}
\hline No & Masa Penyebaran Kuesioner & Populasi & Sampel \\
\hline 1. & Oktober'2015 & 67 & 22 \\
\hline 2. & November'2015 & 69 & 24 \\
\hline 3. & Desember'2015 & 64 & 21 \\
\hline & Jumlah & $\mathbf{2 0 0}$ & $\mathbf{6 7}$ \\
\hline
\end{tabular}

Sumber : Data Sekunder - diolah

\section{HASIL PENELITIAN}

\section{Gambaran Umum Obyek Penelitian}

PT. Asri Pancawarna (PT. APW) ialah perusahaan yang memproduksi keramik granit Indogress dan Decogress. Perusahaan ini tidak hanya memenuhi kebutuhan pasar domestik saja melainkan juga mancanegara seperti Korea, Taiwan, Jepang, Malaysia, Thailand, Eropa Timur, Yunani, Amerika Serikat, Australia dan Afrika Selatan. Keramik granit dihasilkan melalui teknologi terbarukan yang terbaik serta diimpor dari penjuru Eropa.

PT Asri Pancawarna (PT APW) sebuah perusahaan yang relatif muda didirikan pada pertengahan tahun 2005 yang didedikasikan untuk produksi ubin porselen di bawah merek INDOGRESS dan DECOGRESS untuk memenuhi pasar domestik dan luar negeri premium. Perusahaan ini dipimpin oleh manajemen senior berpengalaman personil, semuanya berasal dari dalam industri keramik.

Ubin diproduksi menggunakan hanya teknologi terbaru yang diimpor dari berbagai mesin dan peralatan pemasok terkemuka di Eropa yang terkenal untuk keandalan mereka unggul. Negara-of-theart teknologi yang digunakan lebih lanjut terkena terus-menerus upgrade dan perangkat tambahan. Dinamis serta inovasi dalam organisasi, dan memposisikan untuk terus maju dan beradaptasi dengan perubahan preferensi dan selera di pasar internasional.

PT Asri Pancawarna sepenuhnya menyadari kebutuhan untuk mengadopsi pendekatan yang bertanggung jawab terhadap kondisi sosial dan lingkungan. Oleh karena itu, perusahaan memenuhi kebutuhan industri di bidang perlindungan lingkungan dan eco-manajemen, mengejar hubungan yang berkelanjutan dan bertanggung jawab dengan klien dengan mengintegrasikan etos Layanan Pelanggan yang kuat dengan pendekatan personal untuk menumbuhkan saling menguntungkan. Perusahaan selalu berusaha untuk menciptakan dan meningkatkan produk-produk yang inovatif dan estetika untuk ruang hidup seluruh dunia.

Produk baris dari PT Asri Pancawarna termasuk dipoles dan kasar ubin meliputi garam \& lada, pelangi, pipa 
Yuli Evitha, Pengaruh Kerelasian Pemasaran Dan Kualitas Produk Terhadap Kepuasan Pelanggan ....

multi, ganda pemuatan, tubuh penuh mengkilap porselen ubin, batu bubuk kering seluruh tubuh dan ubin batu tulis.

VISI PERUSAHAAN : Untuk menjadi terkenal dan dihormati produsen ubin porselen di Asia Tenggara.

MISI PERUSAHAAN : Menjadi terkenal dan dihormati produsen ubin porselen di Asia Tenggara 2013 dengan kekuatan utama dalam: Kualitas, Ketersediaan stok, Layanan, International Exposure (dipasarkan secara global).

Sebagai perusahaan atau industri yang memasarkan produknya tentu mempunyai berbagai persoalan terkait dengan masalah produk serta upaya pemasarannya. Oleh karena itu penulis melakukan penelitian terkait dengan masalah tersebut yaitu sejauh mana pengaruah Kerelasian Pemasaran dan Kualitas Produ Terhadap Kepuasan Pelanggan melalui pengujian terhadap beberapa pelanggan atau customer sebanyak 67 pelanggan.

\section{Pengujian Keabsahan Data}

Hasil pengujian terhadap normalitas, validitas serta reliabilitas dimaksudkan untuk menentukan tingkat kenormalan dalam bahan penelitian, serta validitas data yang digunakan dalam penyebaran angket maupun tingkat riil tidaknya data yang akan diuji.

\section{a. Uji Normalitas}

Tabel 4-1 : Normalitas Data

One-Sample Kolmogorov-Smirnov Test

\begin{tabular}{|ll|r|r|r|}
\hline & & $\begin{array}{l}\text { Kerelasian } \\
\text { Pemasaran }\end{array}$ & $\begin{array}{l}\text { Kualitas } \\
\text { Produk }\end{array}$ & $\begin{array}{l}\text { Kepuasan } \\
\text { Pelanggan }\end{array}$ \\
\hline $\mathrm{N}$ & Mean & 67 & 67 & 67 \\
Normal Parameters & St, & 62,7015 & 63,1493 & 64,4179 \\
& Deviation & 6,22073 & 6,45322 & 6,24536 \\
Most Extreme & Absolute &, 146 &, 165 &, 134 \\
Differences & Positive &, 146 &, 165 &, 117 \\
Kolmogorov-Smirnov Z Z & Negative &,- 142 &,- 147 &,- 134 \\
Asymp. Sig. (2-tailed) & 1,194 & 1,353 & 1,098 \\
\hline
\end{tabular}

a. Test distribution is Normal.

b. Calculated from data.

Tabel diatas menunjukkan bahwa seluruh pernyataan yang diisi oleh 67 responden terhadap ketiga variabel bebas dan terikat adalah normal.

\section{b. Hasil Uji Validitas .}

Pengujian validitas data dilakukan untuk mengetahui komponen atau butir pernyataan yang dibuat signifikan atau valid, dan hsilnya seperti pada tabel berikut :

Tabel 4-2 : Validitas

Case Processing Summary

\begin{tabular}{|l|r|r|}
\hline & N & $\%$ \\
\hline Cases Valid & 67 & 100,0 \\
\hline
\end{tabular}

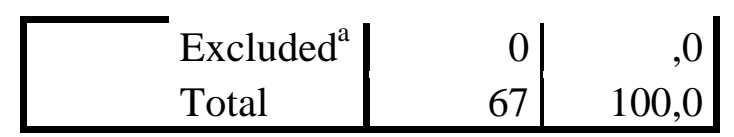

a. Listwise deletion based on all variables in the procedure.

Pengujian validitas terhadap butir kuisioner dengan menggunakan uji korelasi Product Moment Person, untuk mengujian bahwa korelasi tersebut signifikan atau tidak, dan hasilnya valid $100 \%$

\section{c. Hasil Uji Reliabilitas}

Tabel 4 -3 : Reliabilitas

\section{Reliability Statistics}




\begin{tabular}{|r|l|}
\hline $\begin{array}{l}\text { Cronbach's } \\
\text { Alpha }\end{array}$ & $\begin{array}{l}\text { N of } \\
\text { Items }\end{array}$ \\
\hline, 996 & \\
\hline
\end{tabular}

Indek reliabilitas dinyatakan dalam reliebel jika nilai Alpha Cronbach's yang diperoleh paling tidak sebesar 0,700 . Berdasarkan data tabel di atas diketahui nilai Alpha Cronbach's sebesar 0996. Karena nilai Alpha Cronbach's lebih besar dari 0,700 maka kuesioner yang disebarkan adalah reliebel atau handal.

\section{STRATEGI ANALISIS DATA}

Penullis menggunakan strategi dengan melakukan analisis dan pengujian hipotesis sesuai dengan konsep penelitian secara kuantitatif, dengan cara membuktikan benar tidaknya dugaan (hipotesis) awal terhadap variable-variabel yang diteliti.

\section{a. Variabel Kerelasian Pemasaran (X1)}

Berdasarkan hasil pengujian melalui program SPSS for Windows maka diperoleh deskripsi / gambaran statistik tentang variabel Kerelasian Pemasaran sebagai variabel bebas $\mathrm{X} 1$ dengan penjelasan sebagai berikut :

Tabel 4-4 : Variabel Kerelasian Pemasaran
Statistics

Kerelasian Pemasaran

\begin{tabular}{|l|r|}
\hline N $\quad$ Valid & 67 \\
Mean & 0 \\
Std. Error of & 62,7015 \\
Mean &, 75998 \\
Median & 64,0000 \\
Std. Deviation & 6,22073 \\
Variance & 38,697 \\
Range & 22,00 \\
Minimum & 50,00 \\
Maximum & 72,00 \\
\hline
\end{tabular}

Distribusi skor yang diperoleh sebagai hasil penelitian terhadap sejumlah 67 orang responden dengan mempergunakan instrumen kuesioner Kerelasian Pemasaran, diperoleh nilai minimal 50 dan maksimal 72. Range (jangkauan) yang merupakan nilai maksimum dikurangi minimum adalah 23. Artinya jarak antara nilai dari terkecil ke nilai terbesar adalah 22 satuan nilai. Sedangkan nilai rataratanya adalah 62,70 artinya secara umum nilai skor variabel Kerelasian Pemasaran 62,70. Standar deviasinya 6,22 artinya sebaran nilai skor adalah 6,22 di sekitar nilai rata-ratanya. Adapun distribusi dari datanya adalah seperti pada gambar berikut :

Tabel 4-5 : Distribusi Frekuensi Kerelasian Pemasaran

Kerelasian Pemasaran

\begin{tabular}{|r|r|r|r|r|}
\hline & Frequency & Percent & Valid Percent & \multicolumn{2}{|l|}{ Cumulative } \\
& & & Percent \\
\hline 50,00 & 2 & 3,0 & 3,0 & 3,0 \\
52,00 & 1 & 1,5 & 1,5 & 4,5 \\
54,00 & 8 & 11,9 & 11,9 & 16,4 \\
55,00 & 6 & 9,0 & 9,0 & 25,4 \\
Valid 56,00 & 1 & 1,5 & 1,5 & 26,9 \\
58,00 & 2 & 3,0 & 3,0 & 29,9 \\
60,00 & 1 & 1,5 & 1,5 & 31,3 \\
62,00 & 7 & 10,4 & 10,4 & 41,8 \\
63,00 & 3 & 4,5 & 4,5 & 46,3 \\
64,00 & 3 & 4,5 & 4,5 & 50,7
\end{tabular}


Yuli Evitha, Pengaruh Kerelasian Pemasaran Dan Kualitas Produk Terhadap Kepuasan Pelanggan ....

\begin{tabular}{|r|r|r|r|r|}
\hline 65,00 & 10 & 14,9 & 14,9 & 65,7 \\
66,00 & 2 & 3,0 & 3,0 & 68,7 \\
68,00 & 7 & 10,4 & 10,4 & 79,1 \\
70,00 & 13 & 19,4 & 19,4 & 98,5 \\
72,00 & 1 & 1,5 & 1,5 & 100,0 \\
Total & 67 & 100,0 & 100,0 & \\
\hline
\end{tabular}

Distribusi data variabel Kerelasian pemasaran $\left(\mathrm{X}_{1}\right)$ tersebut dapat dilihat dalam Histogram sebagai berikut:

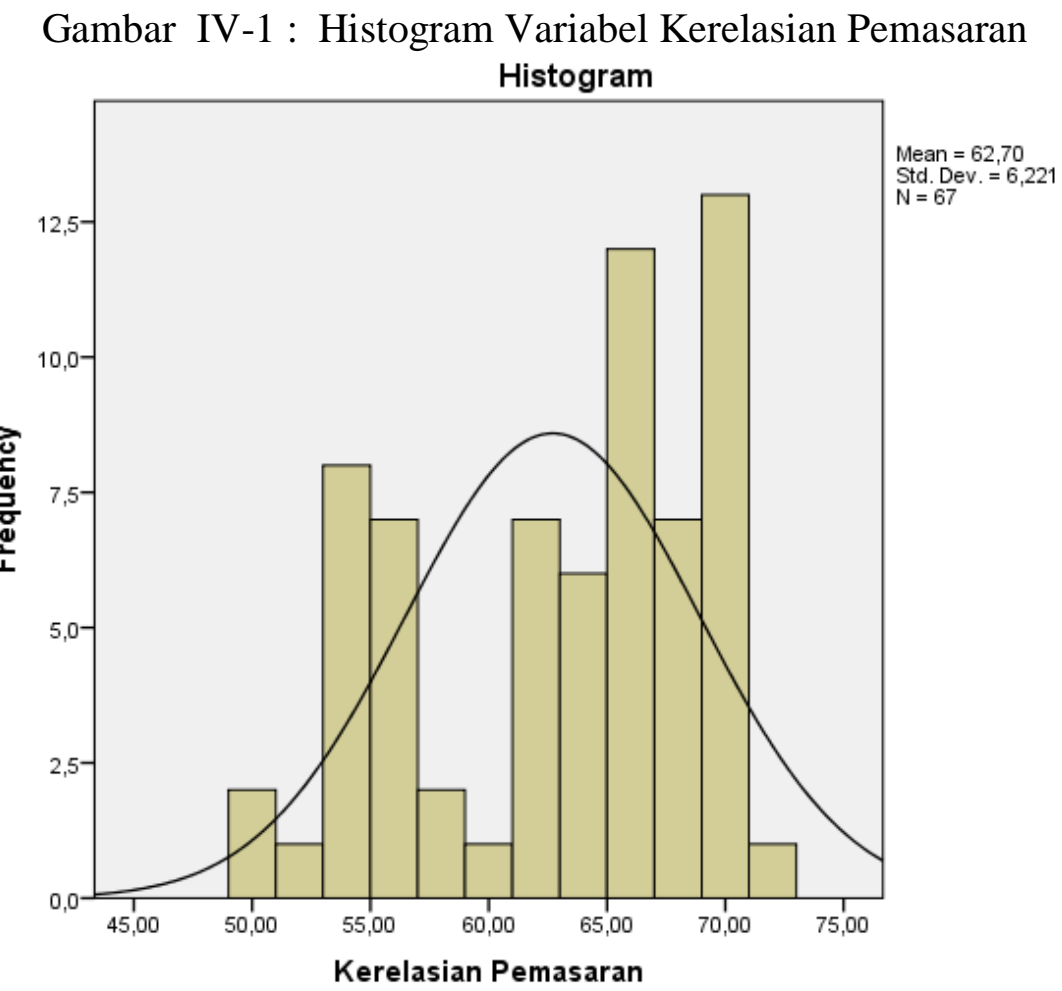

\section{b. Kualitas Produk $\left(\mathbf{X}_{2}\right)$}

Seperti halnya dengan perhitungan pada variabel bebas

Tabel 4-6 : Variabel Kualitas Produk sebelumnya, variabel Kualitas Produk pada PT APW, yang hasilnya disajikan sebagai berikut :

Statistics

Kualitas Produk

\begin{tabular}{|lr|r|}
\hline $\mathrm{N}$ & Valid & 67 \\
Mean & Missing & 0 \\
Std. Error of & 63,1493 \\
Mean &, 78839 \\
Median & 65,0000 \\
\hline
\end{tabular}




\begin{tabular}{|l|r|} 
Std. Deviation & 6,45322 \\
Variance & 41,644 \\
Range & 22,00 \\
Minimum & 50,00 \\
Maximum & 72,00 \\
\hline
\end{tabular}

Distribusi skor yang diperoleh sebagai hasil penelitian terhadap sejumlah 67 orang relasi pada PT APW, diperoleh nilai minimal 50 dan maksimal 72. Range (jangkauan) yang merupakan nilai maksimum dikurangi minimum adalah 22 .
Sedangkan nilai rata-ratanya adalah 63,14 . Standar deviasinya 6,45 artinya sebaran nilai skor adalah 6,45 di sekitar nilai rata-ratanya. Adapun distribusi dari datanya adalah seperti pada gambar berikut :

Tabel 4-7 : Distribusi Frekuensi Kualitas Produk 
Yuli Evitha, Pengaruh Kerelasian Pemasaran Dan Kualitas Produk Terhadap Kepuasan Pelanggan ....

Kualitas Produk

\begin{tabular}{|r|r|r|r|r|}
\hline & $\begin{array}{l}\text { Frequenc } \\
\text { y }\end{array}$ & Percent & \multicolumn{1}{l|}{$\begin{array}{l}\text { Valid } \\
\text { Percent }\end{array}$} & \multicolumn{2}{l|}{$\begin{array}{l}\text { Pumulative } \\
\text { Percent }\end{array}$} \\
\hline 50,00 & 1 & 1,5 & 1,5 & 1,5 \\
51,00 & 1 & 1,5 & 1,5 & 3,0 \\
52,00 & 1 & 1,5 & 1,5 & 4,5 \\
54,00 & 8 & 11,9 & 11,9 & 16,4 \\
55,00 & 7 & 10,4 & 10,4 & 26,9 \\
60,00 & 2 & 3,0 & 3,0 & 29,9 \\
61,00 & 1 & 1,5 & 1,5 & 31,3 \\
62,00 & 2 & 3,0 & 3,0 & 34,3 \\
63,00 & 9 & 13,4 & 13,4 & 47,8 \\
65,00 & 9 & 13,4 & 13,4 & 61,2 \\
66,00 & 4 & 6,0 & 6,0 & 67,2 \\
67,00 & 1 & 1,5 & 1,5 & 68,7 \\
68,00 & 1 & 1,5 & 1,5 & 70,1 \\
69,00 & 8 & 11,9 & 11,9 & 82,1 \\
70,00 & 5 & 7,5 & 7,5 & 89,6 \\
71,00 & 1 & 1,5 & 1,5 & 91,0 \\
72,00 & 6 & 9,0 & 9,0 & 100,0 \\
Total & 67 & 100,0 & 100,0 & \\
\hline
\end{tabular}

Distribusi data variabel Kualitas produk $\left(\mathrm{X}_{1}\right)$ tersebut dapat dilihat dalam Histogram sebagai berikut:

Gambar IV-2 : Histogram Variabel Kualitas Produk

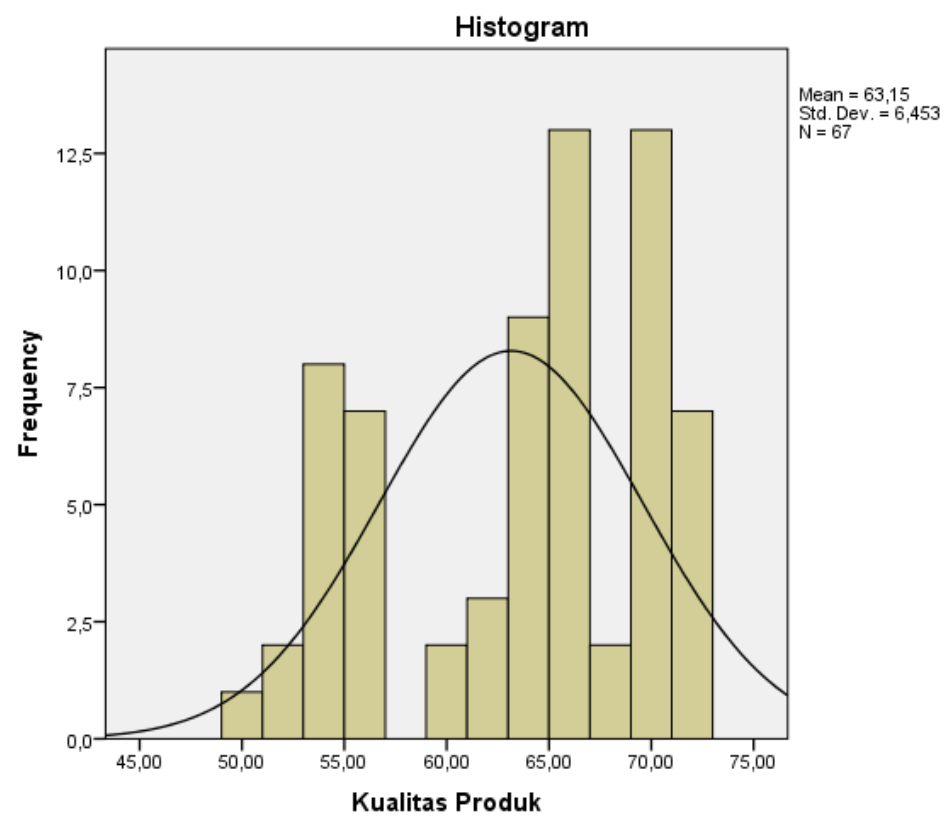




\section{Statistics}

Kepuasan Pelanggan

\begin{tabular}{|l|r|}
\hline N $\quad$ Valid & 67 \\
Mean & 0 \\
Std. Error of & 64,4179 \\
Mean &, 76299 \\
Median & 65,0000 \\
Std. Deviation & 6,24536 \\
Variance & 39,005 \\
Range & 22,00 \\
Minimum & 52,00 \\
Maximum & 74,00 \\
\hline
\end{tabular}

\section{Variabel Kepuasan pelanggan} (Y)

Berdasarkan perhitungan dengan bantuan komputer SPSS for Windows, diperoleh deskripsi statistik variabel Kepuasan pelanggan pada PT APW dapat disajikan sebagai berikut :

Tabel 4-8 : Variabel Kepuasan pelanggan

Distribusi skor yang diperoleh sebagai hasil penelitian terhadap sejumlah 67 orang responden dengan mempergunakan instrumen kuesioner Kepuasan pelanggan, diperoleh nilai minimal 52 dan maksimal 74. Range (jangkauan) yang merupakan nilai maksimum dikurangi minimum adalah 22. Sedangkan nilai rata-ratanya adalah 64,41. Standar deviasinya 6,24. Adapun distribusi dari datanya adalah sebagai berikut :

Tabel 4-9: Distribusi Frekuensi Kepuasan pelanggan

Kepuasan Pelanggan

\begin{tabular}{|r|r|r|r|r|}
\hline & Frequenc & Percent & Valid & \multicolumn{1}{l|}{$\begin{array}{l}\text { Cumulative } \\
\text { Percent }\end{array}$} \\
\hline 52,00 & 2 & 3,0 & 3,0 & 3,0 \\
53,00 & 1 & 1,5 & 1,5 & 4,5 \\
55,00 & 8 & 11,9 & 11,9 & 16,4 \\
58,00 & 7 & 10,4 & 10,4 & 26,9 \\
59,00 & 2 & 3,0 & 3,0 & 29,9 \\
62,00 & 1 & 1,5 & 1,5 & 31,3 \\
63,00 & 2 & 3,0 & 3,0 & 34,3 \\
64,00 & 4 & 6,0 & 6,0 & 40,3 \\
65,00 & 8 & 11,9 & 11,9 & 52,2 \\
66,00 & 2 & 3,0 & 3,0 & 55,2 \\
67,00 & 8 & 11,9 & 11,9 & 67,2 \\
68,00 & 1 & 1,5 & 1,5 & 68,7 \\
70,00 & 7 & 10,4 & 10,4 & 79,1 \\
71,00 & 8 & 11,9 & 11,9 & 91,0 \\
72,00 & 3 & 4,5 & 4,5 & 95,5 \\
73,00 & 1 & 1,5 & 1,5 & 97,0 \\
74,00 & 2 & 3,0 & 3,0 & 100,0
\end{tabular}


Yuli Evitha, Pengaruh Kerelasian Pemasaran Dan Kualitas Produk Terhadap Kepuasan Pelanggan ....

\begin{tabular}{|l|l|l|l|l|}
\hline Total & & 67 & 100,0 & 100,0 \\
\hline
\end{tabular}

Distribusi data variabel Kepuasan pelanggan (Y) tersebut dapat dilihat dalam Histogram sebagai berikut:

Gambar IV-3 : Histogram Variabel Kepuasan pelanggan

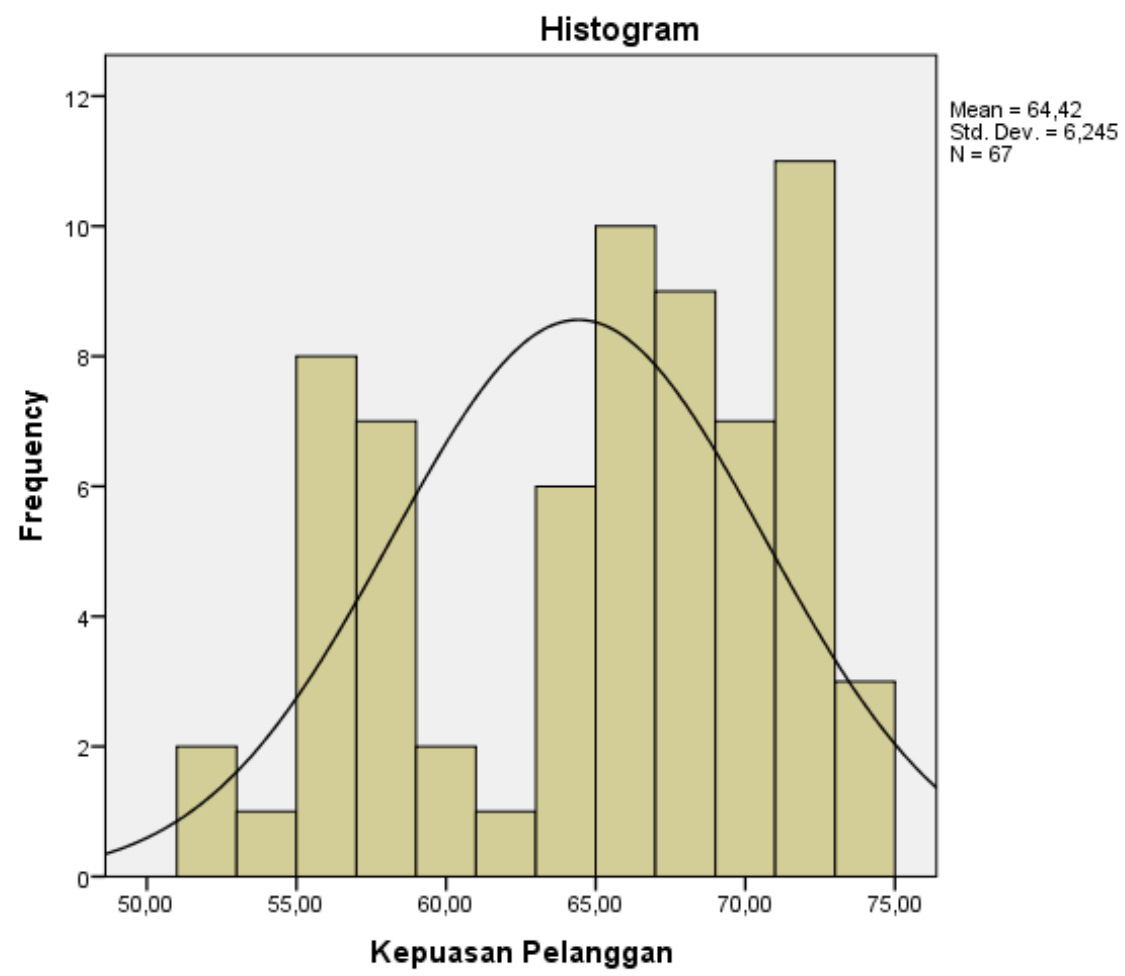

Analisis Hasil Penelitian

\section{Pengaruh Kerelasian Pemasaran (X1) Terhadap Kepuasan pelanggan (Y)}

Dari pengujian yang dilakukan diperoleh hasil sebagai berikut :

Tabel 4-10 
Coefficients $^{\mathrm{a}}$

\begin{tabular}{|c|c|c|c|c|c|}
\hline \multirow[t]{2}{*}{ Model } & \multicolumn{2}{|c|}{$\begin{array}{l}\text { Unstandardized } \\
\text { Coefficients }\end{array}$} & $\begin{array}{l}\text { Standardized } \\
\text { Coefficients }\end{array}$ & \multirow[t]{2}{*}{$\mathrm{t}$} & \multirow[t]{2}{*}{ Sig. } \\
\hline & $\mathrm{B}$ & Std. Error & Beta & & \\
\hline (Constant) & 2,077 & 1,088 & & 1,908 & ,061 \\
\hline $\begin{array}{l}\text { Kerelasian } \\
\text { Pemasaran }\end{array}$ & 994 &, 017 & ,990 & 57,563 & ,000 \\
\hline
\end{tabular}

a. Dependent Variable: Kepuasan Pelanggan

Dari perhitungan SPSS, $\mathrm{t}$ hitung yang diperoleh terhadap b1 adalah sebesar 57,563 sedangkan $t$ tabel dengan derajat bebas 66 pada a $(0,05)$ adalah sebesar 1,96. Dengan demikian, $\mathrm{t}$ hitung $(57,563)>\mathrm{t}$ tabel $(1,96)$, sehingga jelas Ho ditolak dan Hi diterima.

Kondisi itu menunjukkan bahwa variabel bebas $\mathrm{X} 1$ berupa Kerelasian Pemasaran berpengaruh besar terhadap variabel terikat Y berupa Kepuasan pelanggan pada PT APW,
Persamaan regresinya adalah : $\mathrm{Y}=\mathrm{a}+$ $\mathrm{b}_{1} \mathrm{x}_{1}=2,077+0,994 \mathrm{X}_{1}$

Arti dari persamaan diatas adalah bahwa : Setiap ada kenaikan 1 skor pada variabel Kerelasian Pemasaran maka akan meningkatkan Kepuasan pelanggan sebesar 0,994 .

Besarnya pengaruh adalah 0,981 atau 98,1 \%, seperti terlihat pada tabel 4-11 sebagai berikut :

Tabel 4-11 Model summary - Kerelasian Pemasaran

Model Summary ${ }^{\mathrm{b}}$

\begin{tabular}{|l|r|r|l|l|l|}
\hline $\begin{array}{l}\text { Mode } \\
1\end{array}$ & $\mathrm{R}$ & R Square & $\begin{array}{l}\text { Adjusted R } \\
\text { Square }\end{array}$ & $\begin{array}{l}\text { Std. Error of } \\
\text { the Estimate }\end{array}$ & $\begin{array}{l}\text { Durbin- } \\
\text { Watson }\end{array}$ \\
\hline 1 &, $990^{\mathrm{a}}$ &, 981 &, 980 &, 87291 & 2,492 \\
\hline
\end{tabular}

a. Predictors: (Constant), Kerelasian Pemasaran

b. Dependent Variable: Kepuasan Pelanggan

2. Pengaruh Kualitas Produk (X2) Terhadap Kepuasan pelanggan (Y)

Seperti halnya juga pada Uji $t$ sebelumnya, untuk b2 dilakukan pengujian terhadap variabel bebas X2 berupa Kualitas Produk terhadap $\mathrm{Y}$ berupa Kepuasan pelanggan seperti terlihat pada table koefisien $4-12$ sebagai berikut :

Tabel 4-12 : Koefisien - Kualitas Produk

Coefficients $^{\mathrm{a}}$

\begin{tabular}{|c|c|c|c|c|c|}
\hline \multirow[t]{2}{*}{ Model } & \multicolumn{2}{|c|}{$\begin{array}{l}\text { Unstandardized } \\
\text { Coefficients }\end{array}$} & $\begin{array}{l}\text { Standardized } \\
\text { Coefficients }\end{array}$ & \multirow[t]{2}{*}{$\mathrm{t}$} & \multirow[t]{2}{*}{ Sig. } \\
\hline & $\mathrm{B}$ & Std. Error & Beta & & \\
\hline (Constant) & 4,225 & 1,319 & & 3,204 &, 002 \\
\hline $\begin{array}{l}\text { Kualitas } \\
\text { Produk }\end{array}$ & ,953 &, 021 & ,985 & 45,871 & ,000 \\
\hline
\end{tabular}

a. Dependent Variable: Kepuasan Pelanggan

Dari perhitungan SPSS, $\mathrm{t}$ hitung yang diperoleh adalah sebesar 45,871 sedangkan t tabel dengan derajat bebas 66 pada a $(0,05)$ adalah sebesar 1,96. Dengan demikian $t$ hitung 
Yuli Evitha, Pengaruh Kerelasian Pemasaran Dan Kualitas Produk Terhadap Kepuasan Pelanggan ....

$(45,871)>\mathrm{t}$ tabel $(1,96)$, sehingga jelas Ho ditolak dan Hi diterima. Hal ini menunjukkan bahwa Kualitas Produk berpengaruh besar terhadap Kepuasan pelanggan pada PT APW.

Persamaan Regresinya adalah : $\mathrm{Y}=\mathrm{a}$

$+\mathrm{b}_{2} \mathrm{X}_{2}=4,225+0,953 \mathrm{X} 1$
Setiap kenaikan 1 skor variabel Kualitas Produk, maka akan menigkatkan Kepuasan pelanggan sebesar 0,953

Pada tabel 4-13 berikut menunjukkan bahwa besarnya pengaruh adalah 0,970 atau $97,0 \%$.

\section{4-13 : model summary}

Model Summary ${ }^{b}$

\begin{tabular}{|l|r|r|l|l|l|}
\hline $\begin{array}{l}\text { Mode } \\
1\end{array}$ & $\mathrm{R}$ & R Square & $\begin{array}{l}\text { Adjusted R } \\
\text { Square }\end{array}$ & $\begin{array}{l}\text { Std. Error of } \\
\text { the Estimate }\end{array}$ & $\begin{array}{l}\text { Durbin- } \\
\text { Watson }\end{array}$ \\
\hline 1 &, $985^{\mathrm{a}}$ &, 970 &, 970 & 1,08938 & 1,972 \\
\hline
\end{tabular}

a. Predictors: (Constant), Kualitas Produk

b. Dependent Variable: Kepuasan Pelanggan

3. Pengaruh Kerelasian Pemasaran (X1) dan Kualitas Produk (X2) secara bersama-sama Terhadap Kepuasan pelanggan $(\mathrm{Y})$.

Uji $F$ dilakukan untuk menguji hipotesa pertama secara bersamaan atau simultan antara kedua variabel bebas $\mathrm{X} 1$ dan $\mathrm{X} 2$ terhadap $\mathrm{Y}$ melalui rumus koefisien korelasi berganda dengan bantuan pengolahan komputer berdasarkan perhitungan SPSS, diperoleh nilai koefisien $\mathrm{F}_{\text {hitung }}$ sebagai berikut :

Tabel 4-14 : Anova - Kepuasan pelanggan

ANOVA $^{\mathrm{a}}$

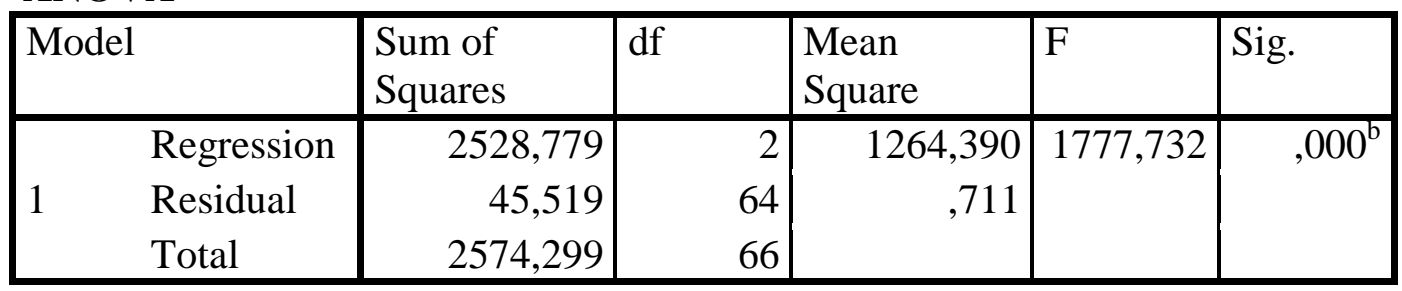

a. Dependent Variable: Kepuasan Pelanggan

b. Predictors: (Constant), Kualitas Produk, Kerelasian Pemasaran

Dengan bantuan pengolahan komputer berdasarkan perhitungan SPSS tersebut diperoleh $F_{\text {hitung }} 1,777,732$. Sedangkan, harga kritis nilai $F_{\text {tabel }}$ dengan derajat bebas pembilang 2 dan penyebut 66 pada a $(0,05)$ sebesar 3,07.

Dengan demikian, $F$ hitung $(1,777,732)>\mathrm{F}$ tabel $(3,07)$, sehingga jelas Ho ditolak dan $\mathrm{Hi}$ diterima. Hal ini menunjukkan bahwa secara bersama-sama

Tabel 4-15 - Model Summary

Model Summary ${ }^{\text {b }}$ variabel bebas X1 (Kerelasian Pemasaran) dan variabel bebas X2 (Kualitas Produk) berpengaruh besar terhadap variabel terikat $\mathrm{Y}$ (Kepuasan pelanggan) pada PT APW.

Adapun besarnya pengaruh Kerelasian pemasaran (X1) dan Kualitas produk (X2) secara bersama-sama terhadap Kepuasan pelanggan (Y) adalah 0,982 atau 98,2 \%, seperti terlihat pada tabel summary 4-15 (R square) sebagai berikut : 


\begin{tabular}{|l|r|r|l|l|l|}
\hline $\begin{array}{l}\text { Mode } \\
1\end{array}$ & $\mathrm{R}$ & $\mathrm{R}$ Square & $\begin{array}{l}\text { Adjusted R } \\
\text { Square }\end{array}$ & $\begin{array}{l}\text { Std. Error of } \\
\text { the Estimate }\end{array}$ & $\begin{array}{l}\text { Durbin- } \\
\text { Watson }\end{array}$ \\
\hline 1 &, $991^{\mathrm{a}}$ &, 982 &, 982 &, 84335 & 2,365 \\
\hline
\end{tabular}

a. Predictors: (Constant), Kualitas Produk, Kerelasian Pemasaran

b. Dependent Variable: Kepuasan Pelanggan berikut :

Adapun persamaan regresi linier berganda dapat dilihat pada tabel koefisien 4-16 sebagi Tabel : 4-16 : Koefisien

\section{Coefficients $^{\mathrm{a}}$}

\begin{tabular}{|c|c|c|c|c|c|c|}
\hline \multirow{2}{*}{\multicolumn{2}{|c|}{ Model }} & \multicolumn{2}{|c|}{$\begin{array}{l}\text { Unstandardized } \\
\text { Coefficients } \\
\end{array}$} & \multirow{2}{*}{$\begin{array}{l}\text { Standardized } \\
\text { Coefficients } \\
\text { Beta }\end{array}$} & \multirow[t]{2}{*}{$\mathrm{t}$} & \multirow[t]{2}{*}{ Sig. } \\
\hline & & $\mathrm{B}$ & Std. Error & & & \\
\hline \multirow{3}{*}{1} & (Constant) & 2,366 & 1,058 & & 2,235 &, 029 \\
\hline & $\begin{array}{l}\text { Kerelasian } \\
\text { Pemasaran }\end{array}$ & ,735 & , 110 & ,733 & 6,668 & ,000 \\
\hline & Kualitas Produk & ,252 & , 106 & ,261 & 2,374 & 021 \\
\hline
\end{tabular}

a. Dependent Variable: Kepuasan Pelanggan

Persamaan regresinya adalah : $\mathrm{Y}=\mathrm{a}+$ $\mathrm{b}_{1} \mathrm{X}_{1}+\mathrm{bX} \mathrm{X}_{2}=2,366+0,735_{1} \mathrm{X}_{1}+0,252_{2} \mathrm{X}_{2}$ Dimana,

$$
\begin{aligned}
& \mathrm{Y}=\text { Kepuasan pelanggan } \\
& \mathrm{X} 1=\text { Kerelasian Pemasaran } \\
& \mathrm{X} 2=\text { Kualitas Produk }
\end{aligned}
$$$$
\text { Dari persamaan regresi diatas }
$$
menunjukkan bahwa apabila ada kenaikan 1 skor Kerelasian Pemasaran akan meningkatkan kenaikan Kepuasan pelanggan sebesar 0,735 dengan asumsi bahwa variabel Kualitas Produk tetap. Sebaliknya jika ada kenaikan 1 skor Kualitas Produk, maka akan meningkatkan Kepuasan pelanggan sebesar 0,252 dengan asumsi variabel Kerelasian Pemasaran tetap.

\section{Koefisien Determinasi}

Koefisien determinasi merupakan kuadrat dari nilai koefisien korelasi yang digunakan untuk mengetahui tingkat keragaman pada variabel terikat $\mathrm{Y}$ yang dapat dijelaskan oleh perbedaan variabel bebas.

Besarnya nilai koefisien determinasi diperoleh melalui tabel 4-15 diatas dimana diperoleh perhitungan SPSS adalah sebesar 0,982 . Hal ini menunjukkan bahwa 98,2 \% keragaman variabel Kepuasan pelanggan pada PT APW, disebabkan oleh keragaman variabel Kerelasian Pemasaran (X1) dan variabel Kualitas Produk (X2), sedangkan sisanya sebanyak $1,9 \%$ disebabkan oleh faktor lain yan tidak diteliti dan disebut epsilon, seperti Motivasi kerja, disiplin kerja, Profesionalisme, Sarana prasarana, lingkungan kerja, kompetensi relasi, dan faktor-faktor lainnya.

\section{PEMBAHASAN}

1. Pengaruh Kerelasian pemasaran Terhadap Kepuasan pelanggan pada PT APW.

Pada Uji t menunjukkan bahwa faktor Kepuasan pelanggan dipengaruhi oleh Kerelasian Pemasaran di PT APW, karena besarnya pengaruh Kerelasian Pemasaran sebesar 98,2 \%, hal ini menunjukkan betapa pentingnya faktor Kerelasian Pemasaran dalam kaitannya dengan hubungan baik dengan pelanggan melalui berbagai potongan atau diskon yang menarik 
Yuli Evitha, Pengaruh Kerelasian Pemasaran Dan Kualitas Produk Terhadap Kepuasan Pelanggan ....

agar mampu mempertahanankan pelanggan tetap untuk membeli produk.

Sebagai contoh adalah pada pembelian ulang yang ketiga oleh seorang relasi atau pelanggan terhadap produk PT APW pihak pembeli meminta diskon terhadap barang tersebut, sedangkan dari pihak perusahaan tidak memberikannya, maka ada kemungkinan pihak pelanggan akan berpindah pada perusahaan lain.

Dari contoh kasus diatas, membuktikan bahwa kebijakan memberikan potongan (diskon) terhadap barang yang berulang dibeli oleh pelanggan tetap perlu dilakukan untuk menarik simpati bagi pembeli, jika tidak akan berdampak buruk bahkan dapat merugikan perusahaan. Kerelasian Pemasaran (melalui pemberia diskon), maka diharapkan Kepuasan pelanggan pada PT APW akan meningkat, sebagaimana pendapat pakar yang mendefinisikan pengertian kerelasian pemasaran "relationship marketing is defined as the process of establishing, maintaining and enhancing, and when necessary terminating relationships with customers, for the benefit of all involved parties, through a process of making and keeping promises." (Grönroos, 2011:245). Yang mempunyai arti "hubungan pemasaran didefinisikan sebagai proses membangun, menjaga dan meningkatkan, dan bila perlu mengakhiri hubungan dengan pelanggan, untuk kepentingan pihak semua yang terlibat, melalui proses pembuatan dan menjaga janji-janji."

Berkaitan dengan penelitian terdahulu, hasil penelitian mempunyai relevansi dan kesamaan bahwa Kerelasian Pemasaran berpengaruh kuat terhadap Kepuasan pelanggan, meskipun dalam penelitian ada perbedaan tentang waktu penelitian, lokus atau tempat serta jumlah responden.

\section{Pengaruh Kualitas produk Terhadap Kepuasan pelanggan pada PT APW.}

Faktor Kualitas Produk berpengaruh positif dan signifikan terhadap Kepuasan pelanggan pada PT APW nilai pengaruhnya sebesar $97,0 \%$. Kondisi ini sudah sangat wajar, karena semakin baik Kualitas Produk maka akan semakin meningkat Kepuasan pelanggan di PT APW.

Relasi di lingkungan PT APW akan merasa puas dalam menerima barang yang dibutuhkan dengan kualitas yang diinginkan. Kualitas Produk yang baik dan dapat diberikan oleh PT APW, melalui upaya produk yang dihasilkan memenuhi standar Kualitas Nasional Indonesia (SNI) dan perusahaan mampu memberikan kualitas produk secara berkelanjutan (suistanable) dimana setiap produk yang dihasilkan sesuai dengan harapan pelanggan secara terus menerus. Jaminan kualitas juga perlu dintegrasikan ke dalam semua proses dan fungsi organisasi. Sebagaimana dicontohkan pada kasus diatas, jika semua proses produkdi mengacu pada kualitas yang diinginkan pelanggan, maka pelanggan akan merasa puas, sehingga kasus diatas dapat dihindari.

Dengan demikian, setiap anggota organisasi di PT APW dimulai dari Direktur sampai dengan aparatur dibawahnya perlu menciptakan Kualitas Produk yang baik sesuai dengan keinginan pelanggan, agar pelanggan merasa puas sehingga pelanggan akan berusaha tetap membeli produk dari PT APW.

Jika dikaitkan dengan penelitian terdahulu menunjukkan pesamaan dari hasil penelitian yaitu bahwa Kualitas Produk mempunyai pengaruh positif dan signifikan terhadap Kepuasan pelanggan, walaupun ada perbedaan dalam hal 
jumlah responden, waktu penelitian serta lokus penelitian.

Sehingga dengan demikian, penggunaan variabel Kualitas Produk cukup tepat dan relevan untuk mengetahui variabel yang mempengaruhi Kepuasan pelanggan pada PT APW.

\section{Pengaruh Kerelasian Pemasaran dan Kualitas Produk secara bersama-sama Terhadap Kepuasan pelanggan pada PT APW.}

Besarnya pengaruh Kerelasian

Pemasaran dan Kualitas Produk terhadap Kepuasan pelanggan adalah sebesar $98,2 \%$, pengaruh yang sangat kuat sehingga apabila perusahaan dapat mewujudkan Kerelasian Pemasaran didukung oleh Kualitas Produk maka tentu Kepuasan pelanggan akan meningkat.

PT APW melayani pelanggan dengan berbagai karakter dan keinginan untuk dilayani dengan baik, sehingga mempertahankan relasi pemasaran melalui pemberian diskon atau potongan harga terhadap barang bagi pelanggan tetap dapat mendukung terciptanya Kepuasan pelanggan. . Selain itu jika Kualitas Produk yang diberikan PT APW secara bersamaan dilaksanakan dengan persepsi yang sama untuk menarik pelanggan, maka niscaya Kepuasan pelanggan akan menjadi baik.

Jika dikaitkan dengan penelitian terdahulu menunjukkan bahwa Kerelasian Pemasaran dan Kualitas Produk secara bersama-sama berpengaruh terhadap Kepuasan pelanggan, meskipun ada perbedaan dalam hal lokus penelitian, jumlah responden serta waktu penelitian.Sehingga dengan demikian dapat dikatakan bahwa penggunaan variabel Kerelasian Pemasaran dan Kualitas Produk untuk mengetahui fenomena Kepuasan pelanggan sudah tepat.

Dengan demikian penggunaan Kerelasian Pemasaran dan Kualitas Produk sebagai instrumen penelitian sudah tepat untuk mengetahui pengaruhnya terhadap Kepuasan pelanggan.

\section{KESIMPULAN DAN SARAN}

\section{A. Kesimpulan}

Dari hasil analisis serta pembahasan yang telah dijelaskan, maka dapat di ambil kesimpulan antara lain :

1. Kerelasian pemasaran berpengaruh terhadap Kepuasan pelanggan. Hal ini dibuktikan dengan hasil perhitungan menunjukkan bahwa t hitung variabel Kerelasian pemasaran > dari pada $t$ tabel, sehingga dengan demikian disimpulkan bahwa Kerelasian pemasaran berpengaruh besar dan signifikan terhadap Kepuasan pelanggan, dan besarnya pengaruh adalah 98,0 \%

2. Kualitas produk berpengaruh terhadap Kepuasan pelanggan. Hal ini dibuktikan dengan hasil perhitungan menunjukkan bahwa t hitung Kualitas produk > dari pada t tabel sehingga dapat disimpulkan bahwa variabel bebas Kualitas produk mempunyai pengaruh besar dan signifikan sebesar 97,0 \% terhadap variabel Kepuasan pelanggan.

3. Pada pengujian regresi berganda dengan menggunakan Uji $F$ menunjukkan bahwa variabel bebas Kerelasian pemasaran dan variabel bebas Kualitas produk secara bersamasama mempunyai pengaruh besar dan signifikan sebesar 98,2 \% terhadap variabel terikat Kepuasan pelanggan, karena F hitung > F tabel.

\section{B. Saran}

Berdasarkan kesimpulan di atas, saran-saran yang bisa disampaikan dalam penelitian ini adalah: 
Yuli Evitha, Pengaruh Kerelasian Pemasaran Dan Kualitas Produk Terhadap Kepuasan Pelanggan ....

1. Kebijakan Pimpinan Perusahaan

a. Perlunya menjalin Kerelasian pemasaran melalui pemberian diskon atau potongan pada PT APW mengingat perusahaan menjual produk secara kontinyu yang diperlukan oleh pelanggan, sehingga untuk mengikat pelanggan perlu ddiperlukan diskon atau potongan agar pelanggan merasa puas.

b. Untuk memberikan kebijakan kepada Kepala bagian marketing membuat atau menentukan harga beserta potongan sesuai dengan batasan yang diberikan oleh manajemen perusahaan, serta memberikan pelatihan mengenai promosi serta memberikan reward berupa insentif kepada tim marketing jika mampu meningkatkan penjualan serta mampu menciptakan Kepuasan pelanggan.

2. Kepada Bagian Marketing :

a. Mengingat banyaknya pelanggan yang ingin mendapatkan potongan atau diskon serta membutuhkan pelayanan yang baik, sehingga disarankan agar bagi pelanggan tetap diberikan potongan atau diskon sampai batas tertentu sesuai kebijakan perusahan untuk membangun pencitraan serta melayani dengan baik para pelanggan.

b. Selain itu bagian produksi disarankan untuk mempertahankan bahkan mampu meningkatkan Kualitas produk yang lebih baik . Kepada bagian pemasaran agar melayani pelanggan dengan memprioritaskan keramah tamahan, sikap yang baik serta selalu sigap untuk memberikan bantuan kepada pelanggan.

\section{DAFTAR PUSTAKA}

Afnita, Ening Nur. 2008.Analisis Pengaruh Kualitas Pelayanan, Fasilitas danHarga Terhadap Kepuasan Konsumen Pengguna Jasa Kereta ApiEksekutif Argo Sindoro

Anderson, E. W.,et al. 1994.Customer Satisfaction, Market Share, and Profitability: Findings from Sweden. Journal of Marketing, Vol. 58, No.1 (January, pp. 53-56).

Anderson, J. C.,et al.1993.Customer Value Assessment in Business Markets: AState-of-Practice Study. Journal of Business to Business Marketing,Vol.1, No. 1, pp. 3-30.

Andi Yulianto. 2003. Analisis Quality Function Deployment (QFD):The Voice of Customer untuk Menghasilkan Kualitas Jasa (Studi kasus pada PT. Kereta Api Indonesia).Media Riset Bisnis \&Manajemen Vol. 3, No. 2, pp. 184 - 201.Sudarmadi, Dyah Hasto Palupi. Majalah SWA 24/XVII/22 November-2 Desember 2001.

Aritonang, Lerbin. 2005.Kepuasan Pelanggan: Pengukuran dan Penganalisisan dengan SPSS. Jakarta: Gramedia.Buttle,

Bagyo. 2006. Analisis Faktor-Faktor yang Mempengaruhi Kepuasan Pelanggan dan Pengaruhnya Terhadap Loyalitas Pelanggan (Studi pada Bank BRI Demak).Jurnal Sains Pemasaran Indonesia Volume V, No. 2, halaman 193-210.

Butz, H. E., Jr. and L. D. Goodstein. 1996. Measuring Customer Value: Gaining the Strategic Advantage.Organizational Dynamics, Vol. 24 (Winter, pp.6377).

Dwi Kartini Yahya. 2002. Perilaku Konsumen Jilid 2 Edisi Kelima.Jakarta: Erlangga.Mujiharjo, 
Edvardsson, B.,et al. 2000.The Effects of Satisfaction and Loyalty on Profits and Growth: Products vs Services,Total Quality Management,Vol. 11,No. 7, pp. 917927.

Engel, James et al, 1994.Perilaku Konsumen Jilid 2, Binarupa Aksara, Jakarta

Fariza, Diana. 2008.Analisis Faktor-Faktor yang Mempengaruhi Kepuasan Pelanggan Indosat di Kota Semarang

Ferdinand, Augusty. 2006.Metode Penelitian Manajemen. Semarang: BPUNDIP.

Fornell, C. 1992. A National Customer Satisfaction Barometer: The Swedish Experience. Journal of Marketing, Vol. 55, No. 1 (January, pp. 621).

Fornell, C.,et al.1996.The American Customer Satisfaction Index: Nature, Purpose, and Findings. Journal of Marketing, Vol. 60, No. 4 (October, pp. 7-18).

Francis. 2007.Customer Relationship Management (Manajemen Hubungan Pelanggan) Concepts and Tools.Malang: Bayumedia Publishing.

Ghozali, Imam. 2009.Aplikasi Analisis Multivariate dengan Program SPSS. Semarang: BP UNDIP.

Gregorius Chandra. 2005. Service, Quality \& Satisfaction. Yogyakarta: Penerbit Andi. www.kedaidigital.com diakses pada 3 Januari 2010.

Holbrook, M. B. 1994. "The Nature of Customer Value: An Axiology of Services in the Consumption Experience" in Rust, R.T. and R. L. Oliver (eds.), Service Quality: New Directions in Theory and Practice. Thousand Oaks, California: Sage Publications.

Kotler, Philip, Benyamin Molan. 2005. Manajemen Pemasaran Jilid 1.Jakarta:INDEKS Kelompok Gramedia.

Kotler, Philip, Benyamin Molan. 2005. Manajemen Pemasaran Jilid

\section{Jakarta:INDEKS Kelompok}

Gramedia.

Kotler, Philip, Gary Armstrong. 2008. Principles of Marketing Thirteenth Edition. New Jersey: Pearson Education, Inc.

Lupiyoadi, Rambat, Hamdani. 2006. Manajemen Pemasaran Jasa. Jakarta: Salemba Empat.

Margaretha, Moureen. 2004.Studi Mengenai Loyalitas Pelanggan pada DivisiAsuransi Kumpulan AJB Bumi Putera 1912 (Studi Kasus di JawaTengah). Jurnal Sains Pemasaran Indonesia Volume III, No. 3, Desember2004, halaman 289308. Mowen, John C, Michael Minor,

Nasution, MN. 2001. Manajemen Mutu Terpadu (Total Quality Management).Jakarta: Ghalia Indonesia.

Oliver, R. L. 1997.“A Cognitive Model of The Antecedents and Consequencesof Satisfaction Decisions", Journal of Marketing Research, Vol. 17, No.4, pp. 460-469.Palupi, Dyah Hasto. Majalah SWA 20/XX/30 September13 Oktober 2004.

Parasuraman A., V. A. Zeithaml \& L. L. Berry. 1990."Delivering Quality Service; Balancing Customer Perceptions and Expectations".London:Collier Macmillan Publisers.Sabihaini,

Rangkuti, Freddy. 2006.Measuring Customer Satisfaction: Teknik Mengukurdan Strategi Meningkatkan Kepuasan Pelanggan plus Analisis Kasus PLN-JPJakarta: Gramedia.

Sugiyono. 2001.. Metode Penelitian Bisnis. Bandung: Alfabeta.

Swastha, Basu, Hani Handoko. 1997. Analisis Perilaku

Konsumen.Jakarta:Erlangga.

Tjiptono, Fandy, Anastasia Diana. 2003. Total Quality Management.Yogyakarta: Penerbit Andi.Tjiptono, Fandy,

Tjiptono, Fandy. 2006.Pemasaran Jasa. Malang: Bayumedia Publishing. 
Yuli Evitha, Pengaruh Kerelasian Pemasaran Dan Kualitas Produk Terhadap Kepuasan Pelanggan ....

Zeithaml, V. A. 1988.“Consumer Perceptions of Price, Quality and Value: A MeansEnd Model and Synthesis of
Evidence", Journal of Marketing, Vol. 52, No. 3 (July), pp. 2-22. 